European Journal of Science and Mathematics Education

Vol. 3, No. 1, 2015, 61-76

\title{
Animation model to conceptualize ATP generation: a mitochondrial oxidative phosphorylation
}

\author{
Ananta Kumar Jena \\ Faculty Department of Educational Sciences, Assam University, Silchar-788011, Assam, India \\ For correspondence: akjenaaus@gmail.com
}

\begin{abstract}
:
Adenosine triphosphate (ATP) is the molecular unit of intracellularenergy and it is the product of oxidative phosphorylation of cellular respiration uses in cellular processes. The study explores the growth of the misconception levels amongst the learners and evaluates the effectiveness of animation model over traditional methods. The data obtained from the sixty B.Sc. students found the growing misconception status in the mitochondrial oxidative phosphorylation test. Euclidean Distance Formula was used to analyzing and interpreting the various growing misconception levels among the students and found that $88 \%$ of students have different types of misconception those were rooted in preconception derived from everyday experiences of students. Similarly, Chi-Square test used to observe the effects of the animation model over the "correct" and "misconception" status of the students and it was resulted that misconception levels relatively decreased from $88 \%$ to $15 \%$, and only $15 \%$ of students have the misconception problems. However, Univariate Analysis of Variance used to measure the effectiveness of animation model of mitochondrial oxidative phosphorylation over the control group. It results that $\mathrm{F}_{(1 / 118)} 323.42 \mathrm{P}<0.01$ ) was significant and there existed significant difference in between control and experimental group achievement of ATP generation of mitochondrial oxidative phosphorylation.
\end{abstract}

Keywords: animation model; ATP generation; mitochondria; oxidative phosphorylation

\section{Background}

Mayer's contribution to the field of educational research was Multimedia Learning Theory, now working as an approach of teaching when visual and verbal materials are presented together simultaneously (Mayer, 2009). Literature found that teaching slow learners with computer-animated models shown to high yield performance (Sugapriya \& Ramachandran, 2011) and it helped the teachers in clarifying the misconception of the students (Falvo, 2008; Ross et al. 2008). Obviously, animated movies stimulate students' learning, and engaging in the exciting process of learning science; in general and molecular biology in particular. Prinz et al. (2005) found that the use of 3D animations leads to a better understanding of difficult surgical topics amongst students, especially among the female users. Moreover, the use of animations in the teaching of histology encourages replacing the traditional lecture/laboratory-based histology courses in medical and dental curricula (Brisbourne et al. 2002) and simulates the students' learning behavior (Quinnell et al. 2012; Syrjakow et al. 2000). Similarly, literature found that the use of animation in teaching enable students to learn difficult concepts easier (Mtebe \& Twaakyondo, 2012) and so far learning concern, animation content not only has a significant effect on mathematical abilities, but also learners improved their mathematical abilities far better than that of conventional approaches (Rohendi (2012). Support to the results of earlier studies, it was found that animation model directly guiding the learner's attention to the specific parts of the content those are difficult to conceptualize the students through static pictures (Wouters et al. 2008). Many lectures have been delivered on ATP generation, but still students have misconceptions and these misconceptions were different from mistakes that the students can 
recognize by themselves when confronted with the concept (Abimbola, 1988). A biochemistry-related concept's misconceptions were poorly investigated (Cho et al. 1985). However, the topic of ATP generation and high-energy bond is simple to teach to the pupils who are taking Biology at advanced level (Gayford, 1986). Moreover, teachers' pedagogical content knowledge is crucial to regulate students' understanding (Falk, 2011). The chemiosmotic theories of ATP synthesis explored in a variety of projects or laboratory exercises (Cros \& Fayol, 1988; Glass \& Siddiqi, 2010) but, animation model for A-level Biology students is an exciting approach to understand the addition of water molecules and the removal of hydrogen atoms in various stages of the Krebs cycle (Akeroyd, 2010). Animation model improves learning outcomes because of conceptual understanding of cell biology (Verhoeff et al. 2008). A number of contemporary science scholars are quite actively engaged to teach the advance science concept like; the chemiosmotic hypothesis of ATP synthesis (Lane, 2010; Nath, 2010). Few scholars directly taught that ATP synthases consisted of a membrane-integrated part, $F_{0}$, and a hydrophilic part, $\mathrm{F}_{1}$. The $\mathrm{F}_{1}$ is composed of five different shapes and size of the various subunits: $\alpha, \beta, \gamma \delta$, and $\varepsilon$ interactions, and conformational changes in the subunit positions related to coupling ADP+pi to ATP (Boekema and Lücken, 2004; Misun Kim \& Eunsook Song, 2010; Mitchell, 1961). In fact, to understand the actual concept of ATP generation, laboratory work is sufficient to understand this concept in this biological science rather animation model complex (Kohlhauf et al, 2011; Passarella \& Atlante, 2007). However, recent methods of science teaching are effective to provide remedial action, but still students have misconception (Barnett \& Hodson, 2001; Thoron \& Myers, 2011).

\section{Significance of the study}

Except few, most of literatures argued that animation model highly useful to conceptualize the knowledge of ATP generation from mitochondrial oxidative phosphorylation and it was using to clarify the students' doubt of complex concepts permanently (Mtebe \& Twaakyondo, 2012). However, the application of technology and pedagogy in a single time is a difficult for the teachers. Nevertheless, no such literature found on animation model directly which was based on the misconceptions test of ATP synthesis in mitochondria (Cho et al 1985). A few literatures found that animation cum discussion treatment has the significant effects on achievement of science (Rohendi, 2012). Moreover, students' have the ability to understand the complex respiratory chain in any method, but animation method would be effective over the traditional approach. That is why, the recent study undertaken to assess the potential contribution of animated model to the field of science teaching.

\section{Research questions}

Is it possible to measure the growing misconception status of learners in a misconception test on ATP generation by mitochondrial oxidative phosphorylation? Do certain misconceptions are the barrier of the achievement? If yes, how modern animation method would be effective to clarify the misconceptions. Does the animation model directly affect the achievement of students on ATP generation by mitochondrial oxidative phosphorylation? If so, does the animation model effective over the control group's post achievement test?

\section{Methodology}

\section{Participants}

Sixty under-graduate (B.Sc. $2^{\text {nd }}$ semester) students of a University, aged between 19 and 20 years, were the participants of the study. Out of them, forty students were randomly assigned to the experimental group $(n=40)$ while others were counted as the control group $(n=20)$. However, the experimental group students were treated through the animation cum discussion instruction, and contrast to this, the control group students were treated by traditional instruction. 


\section{Design of the study}

This study was a non-equivalent quasi-experimental design. First of all, Oxidative phosphorylation Concept Test (OPCT), a misconception test was administered to the control and experimental group students to identifying the degree of misconceptions in ATP synthesis. However, the concepts of ATP synthesis, students had studied in the last semester and it was the right time to assess the students' misconception levels. Euclidean Distance Formula used to analyzing and interpreting the scores of the misconception test having various growing misconception levels derived from everyday experiences of students. The control group students were taught through traditional approach and experimental group exposed to animated materials. However, the process of viewing the animation and graphic was under the supervision of the author. After the animation treatment to the experimental group and traditional lecture to control group, a posttest was administered to both the groups of students, and to observe the effects of animation model on "correct" and "misconception" responds of the experimental group students in the Oxidative phosphorylation Concept Test (OPCT), Chi-Square test was used. Similarly, Univariate Analysis of Variance was used to analyze and interpret the effectiveness of animation model of mitochondrial oxidative phosphorylation over the control group. Table 1 shows the schematic representation of the research design of the study.

Table-1 Design of the study

\begin{tabular}{|l|l|c|c|c|}
\hline $\begin{array}{l}\text { Sl. } \\
\text { No. }\end{array}$ & Group & $\begin{array}{c}\text { Pretest/ } \\
\text { Misconception test }\end{array}$ & $\begin{array}{c}\text { Treatment through HD } \\
\text { Animation model }\end{array}$ & Post test \\
\hline 1 & Experimental & $\mathrm{P}^{1}$ & $\mathrm{X}$ & $\mathrm{P}^{2}$ \\
\hline 2 & Control & $\mathrm{P}^{1}$ & & $\mathrm{P}^{2}$ \\
\hline
\end{tabular}

\section{Questionnaire}

\section{Oxidative Phosphorylation Concept Test (OPCT)}

Oxidative phosphorylation Concept Test (OPCT) was developed by following the steps of standardization of a tool. At the planning and the preparation stage of the test, forty items were prepared through the table of specification in oxidative phosphorylation. A group of experts of life science, science education, and measurement and evaluation reviewed the items and finally fifteen items were accepted through primary, secondary, and final tryout. The content validity ratio was $(\mathrm{CVR}=.68)$ and the Cronbach Alpha reliability of the test found 0.76. To assess the students' previous knowledge, understanding, and especially the growing misconceptions levels, oxidative phosphorylation test was administered among the students of control and experimental group. The test has fifteen items and each item of the test has one correct answer and two powerful distracters. The same OPCT was administered to both the experimental and control group as the pre-test (i.e. misconception test), and the post-test. Finally, the responded test sheets were evaluated by three biology teachers having more than 5 years teaching experience in biology.

\section{Instructions Given to Students}

Sixty B.Sc. students of two biology classes were randomly assigned as the experimental group and control group and at the beginning of the instruction; Oxidative Phosphorylation Concept Test (OPCT) was administered to both the group. All the fifteen items of this test were close ended (i.e. multiple choice) having a correct and two strong distracters, and all the items were prepared to identifying the misconception of the learners. Earlier, all the items were prepared with equal difficulty and discrimination power. However, students consumed maximum twenty minutes to respond the items those were evaluated to identifying the levels and types of misconceptions of students. Item no. $1,5,8,10, \& 14$ were evaluated and identified as the preconceived notions (i.e. a type misconception) those the students acquired during their everyday experience and memorized without confirming its reality. After the misconception test, students requested the researcher to answer these items that was 
prior to the animation class. However, within a short interval, the control group received traditional biology instruction and the experimental group received the animation model instruction. Per day 45min (i.e. a period), the researcher taught through traditional and animation model instruction to the control and experimental group respectively and that was continued up to the end of this chapter (see Appendix-I). During the instruction; respiration, glycolysis, Kreb's cycle, oxidative phosphorylation, ATP generation in mitochondria and electron transport system like concepts were discussed in traditional and animation method.

Students of animation group had the opportunities to play the link: http://highered.mcgrawhill.com/sites/0072507470/student_view0/chapter25/animation_electron_trans port_system_and_atp_synthesis_quiz_1_.html and learners' had the freedom to forward, backward, and to run in slow modes or to stop the animated model at any time and at any step (see Supplemental Material 1). The control group received the traditional instruction whereas, the experimental group advised to review the animation model. Worksheets supplied to the students to prepare a flow diagram of ATP synthesis in the classroom sessions, those they observed. Followed by that students were advised to install the CorelDraw 7.0 software in the system to prepare the animation model of different concepts. Misconception of item no.1 was solute i.e. chemiosmosis is the movement of solute ${ }^{* *}$ across a selectively permeable membrane, down their electrochemical gradient. This misconception was the bigger one and negatively influenced to understand other concepts of chemiosmosis and ATP generation that was recognized in the misconception test. The animated picture on chemiosmosis pumped the protons through special channels in the membranes of mitochondria from the inner to the outer compartment. The proton gradient helped the movement of ion (protons) across a selectively permeable membrane, down their electrochemical gradient, which was not possible by a solute. Theoretically and the hypothetical model of Mitchell argued that the matrix of mitochondria contains a high concentration of ions because of oxidation of nutrients that help ion transports from higher concentration to lower concentration (see fig- 1 to understand the chemiosmosis).

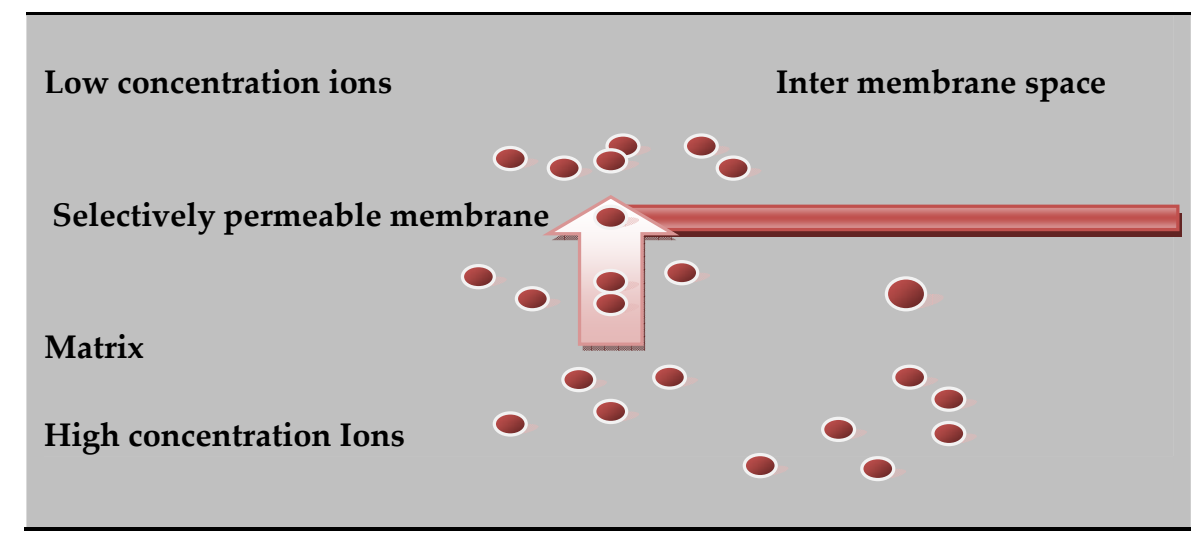

Figure 1 Osmosis (Ion transports from higher concentration to lower concentration through selectively permeable membrane) 
Hydrogen ions (protons) diffused from an area of high proton concentration to an area of lower proton concentration is chemiosmosis. During instruction, learners understood the first stage of the oxidation of glucose i.e. glycolysis and how it proceed to the cytosol (i.e. fluid in the cytoplasm not immediately oxidized to $\mathrm{CO}_{2}$ and $\mathrm{H}_{2}$ ). The stoichiometry of glycolysis is explained in the Box-1. During this chemiosmosis, a strong proton gradient builds up in the cristae of mitochondria $(\mathrm{pH}=5)$ that students understood. Finally, a web link: http://www.stark.kent.edu/ cearley/pchem/Krebs/Krebs.htm learners showed and understood how carbohydrates, fats, and proteins included in glucose reduction reaction.

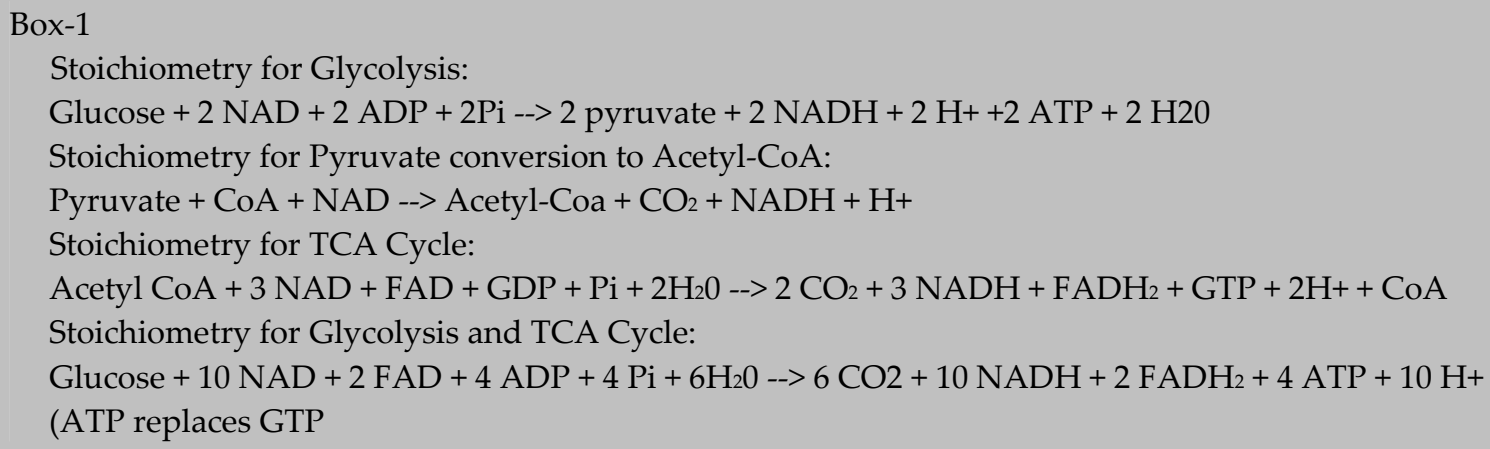

\section{Analysis and result}

Objective 1.To study the growing misconception status of learners in ATP generation by mitochondrial oxidative phosphorylation.

Table-1a 1list of types of misconceptions 1) preconceptual notion 2) nonscientific beliefs 3) conceptual misunderstandings; 4) vernacular misconceptions; and 5) factual misconceptions in the Chemiosmotic hypothesis for ATP synthesis misconception test

\begin{tabular}{|c|c|c|c|c|}
\hline \multirow{2}{*}{$\begin{array}{l}\text { Sl. } \\
\text { No }\end{array}$} & Items & \multicolumn{3}{|c|}{ Options } \\
\hline & & \multicolumn{3}{|c|}{$\%$ response from the students } \\
\hline $1^{\$}$ & $\begin{array}{l}\text { Chemiosmosis is the movement of -------- across a } \\
\text { selectively permeable membrane, down their } \\
\text { electrochemical gradient. }\end{array}$ & Solute $^{* *}(70)$ & Ions*(10) & $\begin{array}{l}\text { Don't } \\
\text { know }(20 \\
) \#\end{array}$ \\
\hline $2^{\#}$ & $\begin{array}{l}\text { Hydrogen --------diffuse from an area of high proton } \\
\text { concentration to an area of lower proton concentration. }\end{array}$ & $\begin{array}{l}\text { ions } \\
(\text { protons })^{*}(20)\end{array}$ & $\operatorname{Gas}^{* *}(73)$ & $\begin{array}{l}\text { Don't } \\
\text { know(7) } \\
\#\end{array}$ \\
\hline $3^{*}$ & $\begin{array}{l}\text { ATP is generated by the movement of hydrogen--------- } \\
\text {--- across a membrane during cellular respiration. }\end{array}$ & $\operatorname{Gas}^{* *}(71)$ & Ions*(21) & $\begin{array}{l}\text { Don't } \\
\text { know }(8) \\
\#\end{array}$ \\
\hline $4^{\oplus}$ & $\begin{array}{l}\text { Peter Mitchell proposed that an electrochemical } \\
\text { concentration gradient of protons across a membrane } \\
\text { could be harnessed to make --------- }\end{array}$ & $\operatorname{ATP}^{*}(22)$ & $\operatorname{ADP} * *(75)$ & $\begin{array}{l}\text { Don't } \\
\text { know(3) } \\
\#\end{array}$ \\
\hline $5^{\$}$ & $\begin{array}{l}\text { Oxidative phosphorylation (or OXPHOS in short) is a --- } \\
\text {------pathway that uses energy released by the } \\
\text { oxidation of nutrients to produce adenosine tri- } \\
\text { phosphate (ATP). }\end{array}$ & Catabolic ${ }^{* *}(77$ & $\operatorname{Metabolic}^{*}(20)$ & $\begin{array}{l}\text { Don't } \\
\text { know(3) } \\
\#\end{array}$ \\
\hline
\end{tabular}




\begin{tabular}{|c|c|c|c|c|}
\hline $6^{*}$ & $\begin{array}{l}\text { NADH coenzyme } \mathrm{Q} \text { oxidoreductase, is known as } \\
N A D H \text { dehydrogenase or--------, is the first protein in the } \\
\text { electron transport chain. }\end{array}$ & complex $I^{*}(21)$ & $\begin{array}{l}\text { complex } \\
\mathrm{II}^{* *}(77)\end{array}$ & $\begin{array}{l}\text { Don't } \\
\text { know(2) } \\
\#\end{array}$ \\
\hline $7^{*}$ & $\begin{array}{l}\text { Succinate-Q oxidoreductase, also known as---------or } \\
\text { succinate dehydrogenase, is the second entry point to the } \\
\text { electron transport chain. }\end{array}$ & complex $I^{* *}(80)$ & complex II*(19) & $\begin{array}{l}\text { Don't } \\
\text { know }(1) \\
\#\end{array}$ \\
\hline $8^{\$}$ & $\begin{array}{l}\text { Q cytochrome c oxidoreductase is known as cytochrome c } \\
\text { reductase, then cytochrome bci complex, or simply--------- } \\
\text {-. }\end{array}$ & $\begin{array}{l}\text { Complex } \\
\text { III*(15) }^{*}\end{array}$ & $\begin{array}{l}\text { complex } \\
I I^{* *}(81)\end{array}$ & $\begin{array}{l}\text { Don't } \\
\text { know }(4) \\
\#\end{array}$ \\
\hline $9^{*}$ & $\begin{array}{l}\text { Cytochrome c oxidase, also known as-----------, is the } \\
\text { final protein complex in the electron transport chain }\end{array}$ & $\begin{array}{l}\text { complex } \\
I I 1^{* *}(82)\end{array}$ & complex $I V^{*}(7)$ & $\begin{array}{l}\text { Don't } \\
\text { know }(1) \\
\#\end{array}$ \\
\hline $10^{\$}$ & $\begin{array}{l}\text { Chemiosmotic Theory states that coupling of ----------- } \\
\text { transfer to ATP synthesis is indirect, via a } \mathrm{H}^{+} \\
\text {electrochemical gradient }\end{array}$ & Proton $^{* *}(85)$ & Electron*(10) & $\begin{array}{l}\text { Don't } \\
\text { know(5) } \\
\#\end{array}$ \\
\hline $11^{\oplus}$ & $\begin{array}{l}\text { ATP produced in the mitochondria must exit to the ----- } \\
\text {-----and used by transport pumps, kinases. At the } \\
\text { same time, ADP and } \mathrm{P}_{\mathrm{i}} \text {, arising from ATP hydrolysis in } \\
\text { the--------, must re-enter the mitochondria to be } \\
\text { converted again to ATP }\end{array}$ & $\begin{array}{l}\text { Matrix } \\
\text { space }^{* *}(86)\end{array}$ & Cytosol $^{*}(9)$ & $\begin{array}{l}\text { Don't } \\
\text { know(5) } \\
\#\end{array}$ \\
\hline $12^{*}$ & $\begin{array}{l}\text { Spontaneous ---------transfer of electrons through } \\
\text { complex I and II, III, and IV is coupled to non- } \\
\text { spontaneous } \mathrm{H}^{+} \text {ejection from the mitochondrial matrix. } \\
\mathrm{H}^{+} \text {ejection creates a membrane potential (DY, negative } \\
\text { in the matrix) and a pH gradient ( } \mathrm{DpH} \text {, alkaline in the } \\
\text { matrix). }\end{array}$ & Electron ${ }^{*}(10)$ & Proton**(85) & $\begin{array}{l}\text { Don't } \\
\text { know(5) } \\
\#\end{array}$ \\
\hline $13^{*}$ & $\begin{array}{l}\mathrm{F}_{1} \mathrm{~F}_{\mathrm{o}} \text { ATP Synthase: Non-spontaneous ATP synthesis is } \\
\text { coupled to spontaneous } \mathrm{H}^{+} \text {transport into the ----------- } \\
\text { compartment. }\end{array}$ & Cytosol*(12) $^{*}$ & Matrix ${ }^{* *}(86)$ & $\begin{array}{l}\text { Don't } \\
\text { know(2) } \\
\#\end{array}$ \\
\hline $14^{\$}$ & $\begin{array}{l}\text { Cyanide, Antimycin, Rotenone and TTFA are-----------in } \\
\text { electron transport system. }\end{array}$ & Inhibitors*(11) & Inducers ${ }^{* *}(87)$ & $\begin{array}{l}\text { Don't } \\
\text { know(2) } \\
\#\end{array}$ \\
\hline $15^{*}$ & $\begin{array}{l}\text { TTFA (thenoyl trifluoroacetone), is an industrial } \\
\text { chemical blocks ------ }\end{array}$ & $\mathrm{NADH}^{* *}(88)$ & $\begin{array}{l}\text { Succinate } \\
\text { oxidation }^{*}(10)\end{array}$ & $\begin{array}{l}\text { Don't } \\
\text { know(2) } \\
\#\end{array}$ \\
\hline
\end{tabular}

${ }^{*}$ Correct response from students

**Wrong response (may be due to misconception)

\#Don't know=unable to attend (strong misconception)

$\%$ (percentage of students' misconception)

$\$$ Item-1,5,8,10,14 preconceived notions type misconception

\#Item-2 nonscientific beliefs type misconception

*Item-3,6,7,9,12,13,15 conceptual misunderstandings type misconception

@Item-4 \& 11 factual misconceptions type misconception

Learners" respond to the Oxidative Phosphorylation Concept Test (OPCT) was evaluated and analyzed (see Table 1a). Resulted that $50 \%$ of students were wrongly responded the Item no. 1 , and $10 \%$ didn't know the actual answer, because they are in dilemma, to choose, whether solute or ions were true response. Similarly, item.no.2, 3, \& 4 were responded with $10 \%, 11 \%$ and $10 \%$ respectively misconceptions among the students. They did not know how the electrochemical concentration gradient of protons across a membrane harnessed to make ATP synthesis, leaded to misconception among the students. Item no. 5 regarding oxidative phosphorylation metabolic path but $(10 \%)$ 
students didn't know the answer and $40 \%$ responded as the catabolic path. Similarly, misconceptions in complex I, complex II, complex III \& complex IV were evaluated. Some students were confused, to select, which enzyme belongs to which complex. They had no clear idea about that NADH dehydrogenase, that was the first protein in the electron transport chain and succinate dehydrogenase was the $2^{\text {nd }}$; Q-cytochrome c oxidoreductase was the $3^{\text {rd }}$ and Cytochrome c oxidase was the $4^{\text {th }}$ protein belongs to complex I, complex II, complex III \& complex IV respectively. Item no. 10 \& $12,(49 \%)$ students responded "didn't know" because they were confused, whether electron or proton directly transfers in chemiosmotic theory during coupling to ATP synthesis or indirect, via a $\mathrm{H}^{+}$ electrochemical gradient and this was because of misconception. Another simple misconception noticed in item no. 11\& 13 that ATP produced in the mitochondria must exit to the ---------- to be used by transport pumps, kinases, etc. and ADP and $P_{i}$, arising from ATP hydrolysis in the--------, must re-enter the mitochondria to be converted again to ATP and responds were "Matrix space / cytosol / don't know". Here, $39 \%$ students answered "matrix space" was the correct response for each blank and $12 \%$ didn't know the answer properly. This was because, misconception among students existed, and it didn't mean they had no idea, their misunderstanding was already killed their knowledge structure to increase their cognitive structure. Similarly, item No 14 \& 15 were the application type questions for the students those students failed to answer. They did not know how Cyanide, Antimycin, Rotenone and TTFA induce or inhibit the electron transport chain or how TTFA (thenoyl trifluoroacetone), an industrial chemical, blocks NADH or Succinate oxidation in the electron transport chin. The responds of item 1 to 15 of B.Sc. students were shown in the graph with maximum range 51-39 was correct, 50-39 misconception and 12-06 didn't know (see Table 1a and figure-2 \& 3).

The $\mathrm{X}$-axis represented the items and Y-axis reflected the percentage of growing misconception respond among the students (see fig 2). The correct respond level was lower than the growing misconception levels. Item no 1, the learners did not correctly respond because they didn't know the actual answer. After that, learners frequent responded the misconception in the whole oxidative phosphorylation test. Out of different types of misconceptions, conceptual misunderstanding was so higher than pre-notion, non-scientific belief, vernacular misconception and factual misconceptions. Here, the $\mathrm{X}$-axis represented the types of misconceptions and $\mathrm{Y}$-axis showed the item wise the percentage of pre-conceptual notion, nonscientific beliefs, conceptual misunderstandings, vernacular misconceptions, factual misconceptions on oxidative phosphorylation test (see fig-3).

Fig-2 items and percentage of misconceptions, correct responses and didn't know responds

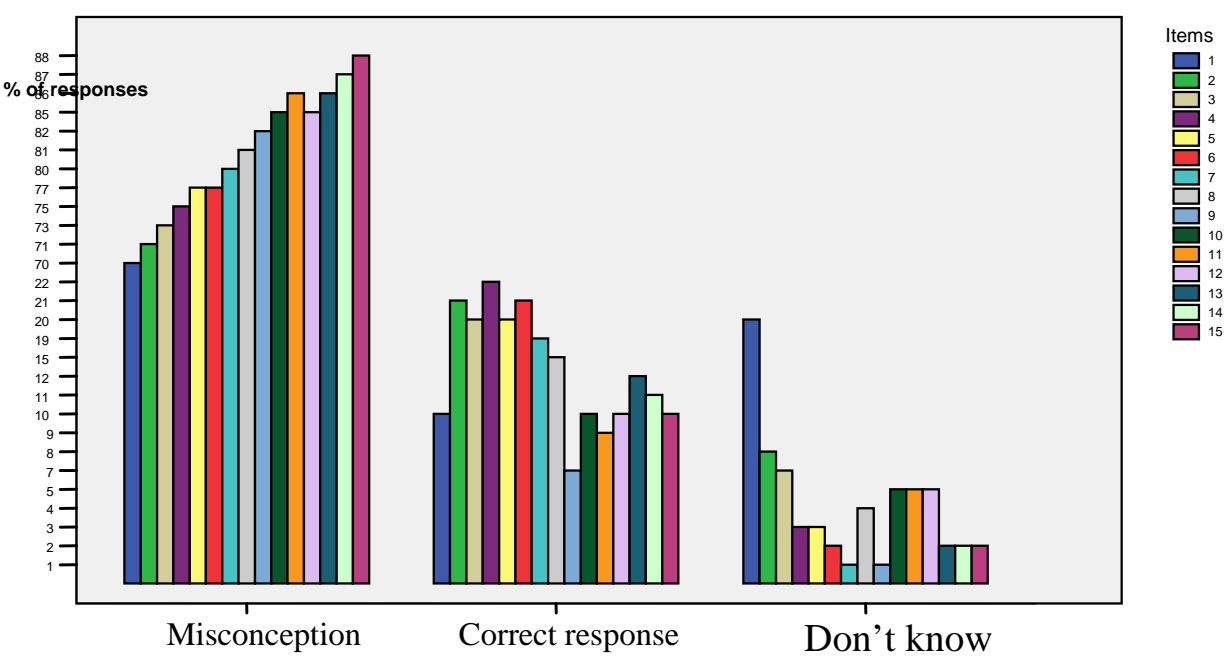

ATP synthesis items response 
Fig-3 The item wise the percentage of pre-conceptual notion, nonscientific beliefs, conceptual misunderstandings, vernacular misconceptions, factual misconceptions on oxidative phosphorylation test

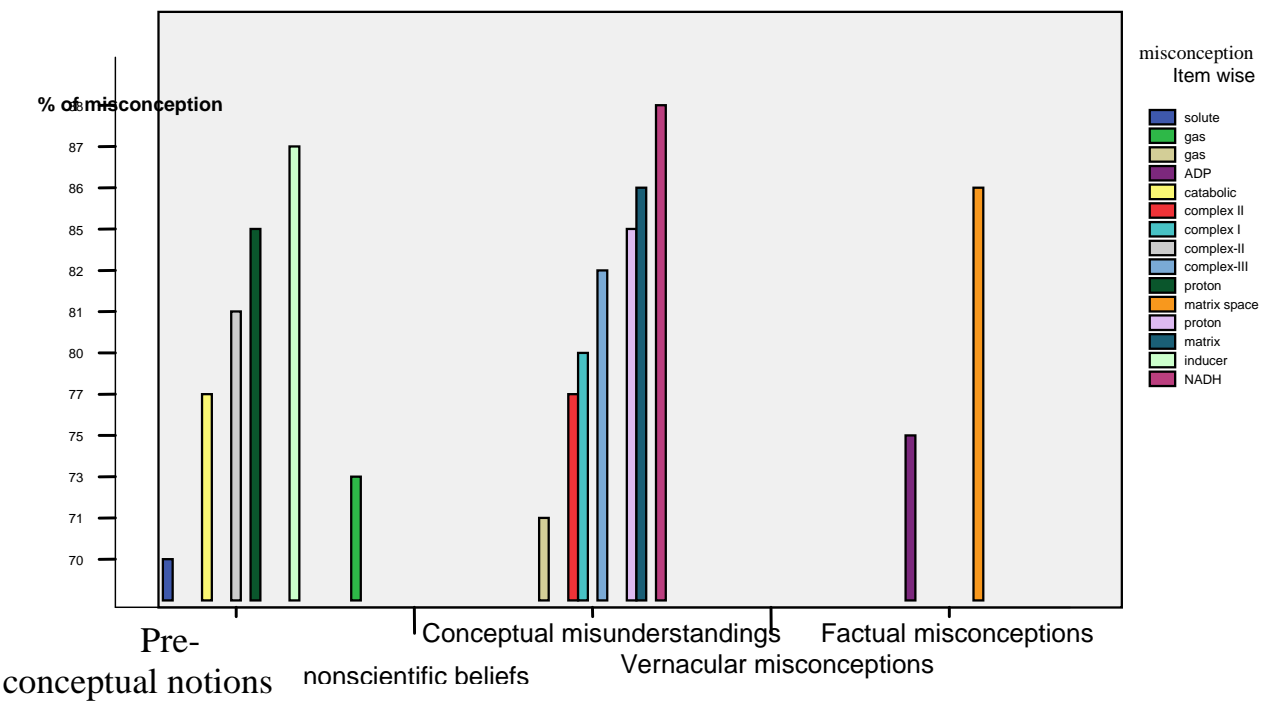

Types of misconception

The data came from misconception test (table-1a) reveals that item no. 1, 5, 8, 10, \& 14 were the preconceived notions, those the students acquired during their everyday experience without confirming its reality because these items were related and previous knowledge based. Similarly, Item no. $3,6,7,9,12,13$, \&15 were the conceptual misunderstandings type misconception identified in the misconception test. Students wrongly responded these in-depth content knowledge type items of the test due to lack of understanding during the previous learning (fig-3).

To analyze and interpret the various growing misconception levels among students, the author used Euclidean Distance Formula. Particularly when we assess the expanse in the plane, we use the formula of Euclidean distance. The Euclidean expanse equation, the expanse between two points in the plane with coordinates $(x, y)$ and $(a, b)$ is:

$$
\operatorname{dist}((x, y),(a, b))=\sqrt{ }(x-a)^{2}+(y-b)^{2}
$$

For that purpose, SPSS used to analyze the distance between misconceptions of the items those were responded by the students. The whole students' overall respond to each option of each item analyzed to realize the relative misconception status.

Table-1b Euclidean Distance to know the growing misconception level among the learners' performance in the ATP generation by mitochondrial oxidative phosphorylation

\begin{tabular}{|c|c|c|c|c|c|c|c|c|c|c|c|c|c|c|c|}
\hline & \multirow[b]{2}{*}{1} & \multirow[b]{2}{*}{2} & \multirow[b]{2}{*}{3} & \multirow[b]{2}{*}{4} & \multirow[b]{2}{*}{5} & \multicolumn{4}{|c|}{ Euclidean Distance } & \multirow[b]{2}{*}{10} & \multirow[b]{2}{*}{11} & \multirow[b]{2}{*}{12} & \multirow[b]{2}{*}{13} & \multirow[b]{2}{*}{14} & \multirow[b]{2}{*}{15} \\
\hline & & & & & & 6 & 7 & 8 & 9 & & & & & & \\
\hline 1 & .000 & & & & & & & & & & & & & & \\
\hline 2 & 1.414 & & & & & & & & & & & & & & \\
\hline 3 & 3.606 & 2.236 & & & & & & & & & & & & & \\
\hline 4 & 5.831 & 4.472 & 2.236 & & & & & & & & & & & & \\
\hline 5 & 8.062 & 6.708 & 4.472 & 2.236 & & & & & & & & & & & \\
\hline 6 & 8.602 & 7.211 & 5.000 & 2.828 & 1.000 & & & & & & & & & & \\
\hline 7 & 11.662 & 10.296 & 8.062 & 5.831 & 3.606 & 3.162 & & & & & & & & & \\
\hline
\end{tabular}




\begin{tabular}{lrrrrrrrrrrrrrrr}
8 & 13.038 & 11.662 & 9.434 & 7.211 & 5.000 & 4.472 & 1.414 & & & & & & & \\
9 & 14.422 & 13.038 & 10.817 & 8.602 & 6.403 & 5.831 & 2.828 & 1.414 & & & & & & \\
10 & 17.493 & 16.125 & 13.892 & 11.662 & 9.434 & 8.944 & 5.831 & 4.472 & 3.162 & & & & & \\
11 & 18.868 & 17.493 & 15.264 & 13.038 & 10.817 & 10.296 & 7.211 & 5.831 & 4.472 & 1.414 & & & \\
12 & 18.601 & 17.205 & 15.000 & 12.806 & 10.630 & 10.000 & 7.071 & 5.657 & 4.243 & 2.000 & 1.414 & & \\
13 & 20.000 & 18.601 & 16.401 & 14.213 & 12.042 & 11.402 & 8.485 & 7.071 & 5.657 & 3.162 & 2.000 & 1.414 & & \\
14 & 21.401 & 20.000 & 17.804 & 15.620 & 13.454 & 12.806 & 9.899 & 8.485 & 7.071 & 4.472 & 3.162 & 2.828 & 1.414 & \\
15 & 22.804 & 21.401 & 19.209 & 17.029 & 14.866 & 14.213 & 11.314 & 9.899 & 8.485 & 5.831 & 4.472 & 4.243 & 2.828 & 1.414 & .000 \\
\hline
\end{tabular}

With reference to table- $1 b$, it was resulted that learners' have a high misconception as compared with the "correct respond" and "don't know" responds. That was interesting to know that item no 1 was the source of misconception and that was hierarchically helped to growing up the misconceptions up to the item no 15 . The tendency of growing misconception rate was (i.e.70 \% to 73\%) increased the distance among and between the items, because of the item- 1 \& 2, those were the starting or the basic misconception which was caused due to misunderstanding among learners and those were reflected in their respond. Similarly, item no. 3 to item no. 10 have similar increasing range of misconception (i.e. $71 \%$ to $86 \%$ ) and the students had the maximum $86 \%$ misconception on item no. 15 (table- 1 ). If the prior or the preliminary knowledge was guessed type or apparent or wrongly acquired then obviously, it could help to grow maximum wrong notions. In this context, the Euclidean Distance statistic used to identify the magnitude of misconception. It was resulted that misconception rate was increased hierarchically in ascending order (i.e. from item no. 1 to 15) with the increased cognitive difficulties (i.e. 000, 1.414, 3.606, 5.831, 8.062, 8.602, 11.662, 13.038, 14.422, 17.493, 18.601, 20.000, 21.401, 22.804 and .000) on ATP generation from mitochondrial oxidative phosphorylation.

Objective 2.To study the effect of animation model on the misconception and achievement of ATP generation by mitochondrial oxidative phosphorylation.

Table-3a percentage of respondents who were correctly responded the items after the animation treatment

\begin{tabular}{|c|c|c|}
\hline \multirow{2}{*}{$\begin{array}{l}\text { Item. } \\
\text { No. }\end{array}$} & Achievement Test & \multirow[t]{2}{*}{ Result Analysis } \\
\hline & Direction: choose a correct response from the options & \\
\hline 1 & $\begin{array}{l}\text { What moves across a selectively permeable membrane, down } \\
\text { their electrochemical gradient in Chemiosmosis? } \\
\text { (a)ion } \\
\text { (b)solute } \\
\text { (C)salt } \\
\text { (d)all of these above }\end{array}$ & $\begin{array}{l}\text { After animation treatment, it was resulted that } 85 \% \text { of } \\
\text { students have correctly responded to the option 'a' ( } i \text {. e. } \\
\text { ion ). This indicated that most of the students have } \\
\text { clarified their misconception regarding electrochemical } \\
\text { gradient in chemiosmosis was the ion transportation, but } \\
\text { earlier } 70 \% \text { of students had the misconception (i.e. solute) } \\
\text { because of the pre- notion. }\end{array}$ \\
\hline 2 & $\begin{array}{l}\text { During cellular respiration what moves across the membrane } \\
\text { and generate ATP? } \\
\text { (a)ion } \\
\text { (b)solute } \\
\text { (C)salt } \\
\text { (d)all of these above }\end{array}$ & $\begin{array}{l}\text { Earlier, } 73 \% \text { students had responded "salt" during the } \\
\text { misconception test but after the animation treatment, } 86 \% \\
\text { (i.e ions) students corrected their misconception. In } \\
\text { cellular respiration ion moves across the membrane and } \\
\text { generate ATP. Here, non-scientific belief created problem } \\
\text { among the students to select or to understand the question } \\
\text { or the text, which the researcher identified among the } \\
\text { students. }\end{array}$ \\
\hline 3 & $\begin{array}{l}\text { What diffuses from an area of high proton concentration to } \\
\text { an area of lower proton concentration? } \\
\text { (a) ion } \\
\text { (b) solute } \\
\text { (C) salt } \\
\text { (d) all of these above }\end{array}$ & $\begin{array}{l}\text { After the animation instruction, } 87 \% \text { students corrected } \\
\text { the item (i.e. ion diffuses from an area of high proton } \\
\text { concentration to an area of lower proton concentration), but } \\
\text { previously learners' misconception was }(71 \%) \text { and the } \\
\text { corrected respond was (ions } 21 \% \text { ). This was because of the } \\
\text { learners' conceptual misunderstanding in the previous } \\
\text { lessons. }\end{array}$ \\
\hline 4 & $\begin{array}{l}\text { Peter Mitchell proposed how could be harnessed to make } \\
\text { ATP? }\end{array}$ & $\begin{array}{l}\text { Peter Mitchell proposed the electrochemical concentration } \\
\text { gradient of protons across a membrane could harness to } \\
\text { make ATP. This was a conceptual understanding after }\end{array}$ \\
\hline
\end{tabular}




\begin{tabular}{|c|c|c|}
\hline & $\begin{array}{l}\text { (a)electrochemical concentration gradient of protons across a } \\
\text { membrane } \\
\text { (b) concentration gradient of protons across a membrane } \\
\text { (C) electrochemical gradient of protons across a membrane } \\
\text { (d)all these bove }\end{array}$ & $\begin{array}{l}\text { knowing the concept of chemiosmosis and ion transport. } \\
\text { Before that } 75 \% \text { learners' had misconception, but after the } \\
\text { treatment effect, learners able to corrected ( } 87 \% \text { ) and } \\
\text { selected the option 'a' (i.e electrochemical concentration } \\
\text { gradient of protons across a membrane). }\end{array}$ \\
\hline 5 & $\begin{array}{l}\text { What is Oxidative phosphorylation (or OXPHOS in short)? } \\
\text { (a) Catabolic pathway uses energy released by the oxidation } \\
\text { of nutrients to produce adenosine tri-phosphate (ATP). } \\
\text { (b) Metabolic pathway uses energy released by the oxidation } \\
\text { of nutrients to produce adenosine tri-phosphate (ATP). } \\
\text { () Anabolic pathway uses energy released by the oxidation of } \\
\text { nutrients to produce adenosine tri-phosphate (ATP). } \\
\text { (d) none of these }\end{array}$ & $\begin{array}{l}\text { All the students attempted the item no. } 5 \text { (i.e. What is } \\
\text { Oxidative phosphorylation (or OXPHOS in short)?and } 87 \% \text { of } \\
\text { students selected option (b) i.e. Metabolic pathway that uses } \\
\text { energy released by the oxidation of nutrients to produce } \\
\text { adenosine tri-phosphate (ATP). Earlier, it was a big } \\
\text { misconception (i.e. } 77 \% \text { ). This type of misconception was } \\
\text { pre-notion that the learner understood through animation } \\
\text { model. }\end{array}$ \\
\hline 6 & $\begin{array}{l}\text { Which is the first protein in the Complex-I of electron } \\
\text { transport chain? } \\
\text { (a)NADH-coenzyme Q oxidoreductase } \\
\text { (b) Succinate-Q oxidoreductase } \\
\text { (C) Q-cytochrome c oxidoreductase } \\
\text { (d)all of these above }\end{array}$ & $\begin{array}{l}\text { Animation instruction helped } 86 \% \text { students to correctly } \\
\text { respond the item (i.e. NADH-coenzyme Q oxidoreductase } \\
\text { was the first protein in the Complex-I of electron transport } \\
\text { chain), but previously learners' misconception was gas } \\
(77 \%) \text {. This was because of the learners' conceptual } \\
\text { misunderstanding at the previous lessons. }\end{array}$ \\
\hline 7 & $\begin{array}{l}\text { What is a second entry point to the electron transport chain? } \\
\text { (a) Q-cytochrome c oxidoreductase } \\
\text { (b) NADH-coenzyme Q oxidoreductase } \\
\text { () Succinate-Q oxidoreductase or succinate dehydrogenase, } \\
\text { (d) both succinate Q-cytochrome c oxidoreductase and } \\
\text { NADH-coenzyme Q oxidoreductase }\end{array}$ & $\begin{array}{l}\text { In the misconception test, it was observed that item7 was } \\
\text { responded and resulted } 80 \% \text { misconception, but after } \\
\text { treatment, } 86 \% \text { correctly responded ' } c \text { ' (i.e. Succinate-Q } \\
\text { oxidoreductase or succinate dehydrogenase). In the electron } \\
\text { transport, chain after NADH coenzyme Q oxidoreductase; } \\
\text { Succinate-Q oxidoreductase or succinate dehydrogenase was } \\
\text { the second entry point of the electron. That was conceptual } \\
\text { misunderstanding and those the students understood after } \\
\text { the animation treatment. }\end{array}$ \\
\hline 8 & $\begin{array}{l}\text { What is cytochrome c reductase bci complex? } \\
\text { (a) complex-IV } \\
\text { (b) Q-cytochrome c oxidoreductase } \\
\text { (C)omplex-III } \\
\text { (d) both b and c }\end{array}$ & $\begin{array}{l}\text { The experimental group respond to item no. } 8 \text {, and } \\
\text { resulted that } 87 \% \text { of students have corrected the item } \\
\text { (i.e.complex-III is cytochrome c reductase, cytochrome bc1 } \\
\text { complex), but previously learners' misconception was } \\
\text { Complex-IV (i.e. } 81 \% \text { ). This was because of the learners' } \\
\text { pre conceptual notion at the previous lessons. }\end{array}$ \\
\hline 9 & $\begin{array}{l}\text { Which is the final protein complex in the electron transport } \\
\text { chain? } \\
\text { (a) Cytochrome c oxidase } \\
\text { (b) Q-cytochrome c oxidoreductase } \\
\text { (c) succinate dehydrogenase } \\
\text { (d) NADH-coenzyme Q oxidoreductase }\end{array}$ & $\begin{array}{l}\text { In the misconception test it was resulted, students' had } \\
82 \% \text { misconception in item no. } 9 \text {, but after treatment } 86 \% \\
\text { students selected the correct response (i.e. Cytochrome c } \\
\text { oxidase). }\end{array}$ \\
\hline 10 & $\begin{array}{l}\text { Chemiosmotic Theory states } \\
\text { (a) The coupling of electron transfer via a } \mathrm{H}^{+} \text {electrochemical } \\
\text { gradient } \\
\text { (b)ATP generation } \\
\text { (Ocoupling of ions } \\
\text { (d)coupling of pi +ADP }\end{array}$ & $\begin{array}{l}\text { Chemiosmotic theory states } \mathrm{F}_{1} \mathrm{~F}_{0} \text { ATPase is the actual } \\
\text { coupling site, where ATP is finally generated due to the } \\
\text { coupling of electron transfer via a } \mathrm{H}^{+} \text {electrochemical } \\
\text { gradient. This was the actual answer for the item no. } 9 \text {. } \\
\text { Earlier, } 82 \% \text { students had conceptual misconception but } \\
\text { after treatment, it was seen that } 86 \% \text { students correctly } \\
\text { responded the item. }\end{array}$ \\
\hline 11 & $\begin{array}{l}\text { Where ATP produced in the mitochondria and transported } \\
\text { to which part? } \\
\text { (a)From cytosol, by the transport pumps, kinases; ADP and } \\
\mathrm{P}_{\mathrm{i}} \text {, arising from ATP hydrolysis in the cytosol and re-enter } \\
\text { the mitochondria to be converted again to ATP } \\
\text { (b) From matrix space, by the transport pumps, kinases; } \\
\text { ADP and } \mathrm{P}_{\mathrm{i}} \text {, arising from ATP hydrolysis in the cytosol and } \\
\text { re-enter the mitochondria to be converted again to ATP } \\
\text { () From mitochondrial outer membrane, by the transport } \\
\text { pumps, kinases; ADP and } \mathrm{P}_{\mathrm{i}} \text {, arising from ATP hydrolysis in } \\
\text { the cytosol and re-enter the mitochondria to be converted } \\
\text { again to ATP } \\
\text { (d)non of these above }\end{array}$ & $\begin{array}{l}\text { In cytosol, the transport pumps, kinase; ADP and } \mathrm{P}_{\mathrm{i}} \text {, } \\
\text { (arises from ATP hydrolyses in the cytosol) re-enter into } \\
\text { the mitochondria to convert again to ATP. This concept } \\
\text { actually needs previous knowledge and conceptual } \\
\text { understanding. Before treatment students had the serious } \\
\text { error ( } 86 \% \text { misconception), but after treatment it was } \\
\text { resulted that } 85 \% \text { of students corrected their } \\
\text { misconception. }\end{array}$ \\
\hline
\end{tabular}




\begin{tabular}{|c|c|c|}
\hline 12 & $\begin{array}{l}\text { What is the role of the electron in respiration for ATP } \\
\text { generation? } \\
\text { (a)Spontaneously electron transfer through complexes I, } \\
\text { complex III, and complex IV are coupled with non- } \\
\text { spontaneous } \mathrm{H}^{+} \text {ejection from the mitochondrial matrix. } \mathrm{H}^{+} \\
\text {ejection creates a membrane potential (DY, negative in the } \\
\text { matrix) and a pH gradient (DpH, alkaline in the matrix). } \\
\text { (b)Randomly electron transfer through complexes I, II, III, } \\
\text { and IV is coupled to non-spontaneous } \mathrm{H}^{+} \text {ejection from the } \\
\text { mitochondrial matrix. } \mathrm{H}^{+} \text {ejection creates a membrane } \\
\text { potential (DY, negative in the matrix) and a pH gradient } \\
\text { (DpH, alkaline in the matrix). } \\
\text { (OSpontaneously electron transfer through complexes I, II, III, } \\
\text { and IV is coupled to non-spontaneous } \mathrm{H}^{+} \text {ejection from the } \\
\text { mitochondrial matrix. } \mathrm{H}^{+} \text {ejection creates a membrane } \\
\text { potential (DY, negative in the matrix) and a pH gradient } \\
\text { (DpH, alkaline in the matrix). } \\
\text { (d)all these above }\end{array}$ & $\begin{array}{l}\text { Previously, the misconception rate among the students in } \\
\text { the item } 12 \text { was }(85 \%) \text {, but after treatment it was } 86 \% \text {. The } \\
\text { electron in respiration for ATP generation was a } \\
\text { spontaneous process and the electron transfer through } \\
\text { complexes I, III, and IV were coupled to non-spontaneous } \\
\mathrm{H}^{+} \text {ejection from the mitochondrial matrix. } \mathrm{H}^{+} \text {ejection } \\
\text { created a membrane potential (DY, negative in the matrix) } \\
\text { and a pH gradient ( } \mathrm{DpH} \text {, alkaline in the matrix). }\end{array}$ \\
\hline 13 & $\begin{array}{l}\text { How } \mathrm{F}_{1} \mathrm{~F}_{0} \text { ATP Synthase work? } \\
\text { (a)The non-spontaneous ATP synthesis is coupled to } \\
\text { s45bvgftrpontaneous } \mathrm{H}^{+} \text {transport into the cytosol } \\
\text { compartment. The pH and electrical gradients created by } \\
\text { respiration are together the driving force for } \mathrm{H}^{+} \text {uptake. } \\
\text { (b) The non-spontaneous ATP synthesis is coupled to } \\
\text { spontaneous } \mathrm{H}^{+} \text {transport into the cytosol compartment. } \\
\text { c) The spontaneous ATP synthesis is coupled to spontaneous } \\
\mathrm{H}^{+} \text {transport into the cytosol compartment. The pH and } \\
\text { electrical gradients created by respiration are together the } \\
\text { driving force for } \mathrm{H}^{+} \text {uptake. } \\
\text { (d) both b and c }\end{array}$ & $\begin{array}{l}\mathrm{F}_{1} \mathrm{~F}_{0} \text { ATPase is a roter or turbine always rotate due to the } \\
\text { continuous flow of } \mathrm{H}^{+} \text {. This spontaneous ATP synthesis is } \\
\text { coupled to spontaneous } \mathrm{H}^{+} \text {transport into the cytosol } \\
\text { compartment. The } \mathrm{pH} \text { and electrical gradients created by } \\
\text { respiration are together the driving force for } \mathrm{H}^{+} \text {uptake. } \\
87 \% \text { of students had corrected the item by choosing the } \\
\text { option ' } \mathrm{c}^{\prime} \text {. Earlier it was } 86 \% \text { of misconception. }\end{array}$ \\
\hline 14 & $\begin{array}{l}\text { What are inhibitors? } \\
\text { (a)all reducers } \\
\text { (b) Cyanide, Antimycin, Rotenone and TTFA are inhibitors in } \\
\text { electron transport system. } \\
\text { Osuccinic and citric acid } \\
\text { (d)both b and c }\end{array}$ & $\begin{array}{l}\text { Earlier, } 87 \% \text { students had the misconceptions but after } \\
\text { animation treatment, } 86 \% \text { of students responded that } \\
\text { Cyanide, Antimycin, Rotenone and TTFA were inhibitors } \\
\text { in electron transport system that was the correct response. }\end{array}$ \\
\hline 15 & $\begin{array}{l}\text { At what stage TTFA block the electron transport chain. } \\
\text { (a) Succinate oxidation stage } \\
\text { (b)complex-II } \\
\text { (B)oth a and b } \\
\text { (d) non of the above }\end{array}$ & $\begin{array}{l}\text { Succinata-FAD-FeS } \\
\text { TTFA } \\
\text { Complex-II TTFA blocks the electron flow and causes } \\
\text { hazard to generate ATP in the mitochondria. Here, } 87 \% \text { of } \\
\text { students have rightly chosen the option ' } b \text { ', but earlier it } \\
\text { was } 88 \% \text { of misconception. }\end{array}$ \\
\hline
\end{tabular}

Table-3b Chi-Square test for the observation of the animation model's effect on "correct" and "misconception" responds.

\begin{tabular}{lcc}
\hline & Types of response & Percentage of response \\
\hline Chi-Square $(\mathrm{a}, \mathrm{b})$ & .000 & 41.067 \\
$\mathrm{df}$ & 1 & 12 \\
Asymp. Sig. & 1.000 & .000 \\
\hline
\end{tabular}

a 0 cells $(.0 \%)$ have expected frequencies less than 5 . The minimum expected cell frequency is 15.0. b 13 cells $(100.0 \%)$ have expected frequencies less than 5 . The minimum expected cell frequency is 2.3 .

Table- $3 \mathrm{~b}$ reveals that after instruction, the no. of correct responds increased over the misconception or the wrong respond. As a result, the numbers of correct responds increased from $85 \%$ to $87 \%$, and the proportionate of distribution among categorical responds changed significantly. In fact, the Chi-sqare 
value $\left(\chi^{2}=41.067 \mathrm{df}=12 \mathrm{p}<.01\right)$ was significant at 0.01 level, but still $15 \%$ students have the serious misconceptions. However, the misconceptions rate decreased from $88 \%$ to $15 \%$, but still $15 \%$ of students have the misconceptions in nonscientific beliefs, conceptual misunderstandings, pre conceptual belief, factual misconceptions, and these students were struggling to clarify their misconception even after the animation treatment on ATP generation and oxidative phosphorylation.

Objective 3. To study the effect of animation model over conventional teaching on the ATP generation by mitochondrial oxidative phosphorylation.

Table-4 Univariate Analysis of Variance of the pre test and post achievement test on ATP generation by mitochondrial oxidative phosphorylation between control group and experimental group.

\begin{tabular}{lrrrrr}
\hline Source & $\begin{array}{l}\text { Type III Sum } \\
\text { of Squares }\end{array}$ & Df & \multicolumn{1}{c}{ Square } & \multicolumn{1}{c}{ F } & \multicolumn{1}{c}{ Sig. } \\
\hline Corrected & $4821.620(\mathrm{a})$ & 1 & 4821.620 & 323.422 & .000 \\
Model & 74575.220 & 1 & 74575.220 & 5002.317 & .000 \\
Intercept & 4821.620 & 1 & 4821.620 & 323.422 & .000 \\
Test & 1759.160 & 118 & 14.908 & & \\
Error & &
\end{tabular}

a R Squared $=.733$ (Adjusted R Squared $=.730$ )

b Weighted Least Squares Regression - Weighted by Animation

The students in the experimental group who were engaged in animation model performed better over the control group students who were engaged in traditional instruction. The Univariate Analysis of Variance of the pre test and post achievement test on ATP generation by mitochondrial oxidative phosphorylation between control group and experimental group resulted that there existed significant difference between the performance of the control group $(\mathrm{M}=12.51 \pm 2.58)$ and the experimental group $(\mathrm{M}=25.62 \pm 2.79)$. The $\mathrm{F}(1 / 118) \quad 323.42 \mathrm{P}<0.01$ was significant and there existed significant difference between control group and experimental on their achievement on ATP generation of mitochondrial oxidative phosphorylation (see table 4).

\section{Discussion}

The present study examined the effectiveness of the animated model and students' used to understand the chemiosmotic hypothesis of ATP synthesis in plant. Students' understanding on the targeted concept was measured by using the misconception test and found that the growing misconception was started from the item no 1 and hierarchically grown up to item no 15 . Before the treatment, $75 \%$ in average had the misconception in ATP generation among the students. In fact, it was found that the animation model has significant effects on the understanding of ATP generation from mitochondrial oxidative phosphorylation in plants. This result was supported by (Luz et al 2008) and indicated that new model intervention have greater significant on students' understanding. Still, $15 \%$ to $12 \%$ students have misconception in each item that tends to need more discussion. Accordingly, teachers and teacher educators would think how to clarify the learner's misunderstanding. Verhoeff et al. (2008) reported that identification of conceptual misunderstanding was the main predictor conceptualization of ATP generation of mitochondrial oxidative phosphorylation. In the present study, throughout the treatment, the experimental group used animation model, while students in the control group received conventional instruction. After instruction, the students thought that Chemiosmotic theory states F1F0 ATPase is the actual coupling site, where coupling of pi+ADP is finally generated due to the coupling of electron transfer via a H+ electrochemical gradient. It means learners have still misconception and they are unable to choose whether ATP or pi+ADP is the correct response for the item no 10? They also believed that the electron in respiration for ATP generation was a random process and the electron transfer through complexes III, IV, and I were coupled to non-spontaneous $\mathrm{H}+$ ejection from the mitochondrial matrix. $\mathrm{H}+$ ejection 
creates a membrane potential (DY, negative in the matrix) and a $\mathrm{pH}$ gradient $(\mathrm{DpH}$, alkaline in the matrix) was the great misconception. This result was supported the idea that misconceptions were strongly hold in their ideas, which were not easily remediated through traditional instructions or through any scientific instructions (Abimbola, 1988). Responses of several students indicated a persistent belief that $85 \%$ of students in the posttest have correctly chosen option 'a' (i.e. ion) indicating that most of the students have been cleared their misconception regarding electrochemical gradient in chemiosmosis, but before instruction they responded "solute". In the same time, the traditional group students responded that solute only moves from higher concentration to lower concentration through a semi permeable membrane. Moreover, some were failing to understand ATP generation from mitochondrial oxidative phosphorylation. Students concluded that ATP generation from mitochondrial oxidative phosphorylation was the ion or electron transport process, and it was not difficult to learn (Stavrianeas, 2005). The students in the experimental group who were engaged in animation model performed better over the control group students who were engaged in traditional instruction.

\section{Conclusion}

The goal of this paper was to know the effectiveness of the animation model in teaching of oxidative phosphorylation and ATP generation by mitochondria. In this study, the growing misconception status of learners in ATP generation from mitochondrial oxidative phosphorylation found high, these were preconceived notions rooted in everyday experiences. Animation model clarified the misconception and positively affected the achievement of ATP generation from mitochondrial oxidative phosphorylation. Animation model is an effective approach for teaching and learning at various levels and it should be used in teacher training programme for the clarification of doubt and misunderstanding of teachers (Bryan et al. 2011). Finally, the author suggested that animation learning is a suitable approach beneficial for students' learning disabilities. The study also indicated that students who studied science with the use of animated movies achieved high in the achievement test of ATP generation in mitochondria compared to students who studied science in a traditional way.

Limitations and Recommendations

The research examined the application of animation model in science teaching but still it is in question, whether learning with animations makes a difference in other contexts as well, such as, social sciences and mathematics? The participants in the study were under graduate students. It remains to be determined wither results would have been different with elementary and secondary schools or college students? It is recommended to examine the effect of animation-based learning on physical and chemical sciences. The author recommends that more animated movies be created for high school and university students.

\section{Acknowledgement}

This article is dedicated to the life science teachers and scientists who are pioneers in mitochondrial research. I thank our colleagues for their great discussion and for sharing their newest research findings with me. I apologize to all those participants who observed the excellent animation movie that I could not be mentioned in this report.

\section{References}

Abimbola, I. O. (1988). The problem of terminology in the study of student conceptions in science. Science Education, 72 (2), 175-184.

Akeroyd, F.M.(2010). Teaching the Kreb's Cycle. Journal of Biological Education, 17 (3), 245-246.

Barnett, J.\& Hodson, D.(2001). Pedagogical context knowledge: Toward a fuller understanding of what good science teachers know. Science Education.85(4), 426-453. 
Boekema,E. and Lücken,U. (2004). The Structure of the CF1 Part of the ATP-Synthase Complex from Chloroplasts. Advances in Photosynthesis and Respiration, 4(8), 487-492, DOI: 10.1007/0-306-48127-8_26.

Brisbourne MA, Chin SS, Melnyk E, Begg DA.(2002). Using web-based animations to teach histology.Anat Rec. 2002 Feb 15,269(1),11-9.

Bryan,R.R.; Glynn,S.M.; Kittleson,J.M.(2011).Motivation, achievement, and advanced placement intent of high school students learning science. Science Education, 95(6), 1049-1065.

Cho, H.H.; Kahle, J. B.; Howard, N. F. (1985). An investigation of high school textbooks as sources of misconceptions and difficulties in genetics and some suggestions for teaching genetics, Science Education. 69, 707-719.

Cros,D., Fayol,M. (1988). Conceptions of second year university students of some fundamental notions in chemistry. International Journal of Science Education, 10, 331-336.

Falk, A. (2012). Teachers learning from professional development in elementary science: Reciprocal relations between formative assessment and pedagogical content knowledge. Science Education, 96(2), 265-290.

Falvo, D. (2008). Animations and simulations for teaching and learning molecular chemistry. International Journal of Technology in Teaching and Learning, 4 (1), 68-77.

Gayford,C. (1986). ATP: A coherent view for school advanced level studies in biology. Journal of Biological Education, 20(1), 2732.

Glass, A. D. M. \& Siddiqi, M. Y. (2010). Potassium-hydrogen ion exchange across barley roots: an introduction to chemiosmotic principles of solute transport. Journal of Biological Education,15(4),289-293.

Kohlhauf, L.; Rutke, U.; Neuhaus, B. (2011). Influence of previous knowledge,language skills and domain-specific interest on observation competency. Journal of science Education,20(5),667-678.

Lane, N, Allen, J.F.; Martin,W. (2010). How did LUCA make a living? Chemiosmosis in the origin of life. BioEssays DOI 10.1002/bies.200900

Luz,M R M P, de Oliveirak,G.A., de Sousa,C.R., and Da PoianLuz,A.T., de Sousa,O., and Da Poiank,A.T. (2008). Glucose as the Sole Metabolic Fuel: The Possible Influence of Formal Teaching on the Establishment of a Misconception About Energyyielding Metabolism Among Students from Rio de Janeiro, Brazil. Biochemistry and molecular biology education, Vol. 36, No. 6, pp. 407-416.

Mayer, R. E. (2009). Multimedia learning (2nd ed). New York: Cambridge University Press.

Misun Kim \& Eunsook Song, 2010 Effects of ATP and ADP on iron uptake in rat heart mitochondria. Animal Cells and Systems Volume 14, Issue 4, 2010 pages 245-252

Mitchell, P. (1961). Coupling of Phosphorylation to Electron and Hydrogen Transfer by a Chemi-Osmotic type of Mechanism. Nature, 191 (4784), 144-148.

Mtebe,J. \& Twaakyondo,H.(2012). Animations effective tools for teaching computer science courses in developing countries.International Journal of Digital Informtion and Wireless, 2(2), 202-207.

Nath,S.(2010). Beyond the Chemiosmotic Theory: Analysis of Key Fundamental Aspects of Energy Coupling in Oxidative Phosphorylation in the Light of a Torsional Mechanism of Energy Transduction and ATP Synthesis - Invited Review Part 2. Journal of Bioenergetics and Biomembranes, 42(4), 301-309, DOI: 10.1007/s10863-010-9295-6.

Passarella, S.; Atlante, A. (2007).Teaching the Role of Mitochondrial Transport in Energy Metabolism Biochemistry and Molecular Biology Education, v35 n2 p125-132

Prinz,A., Bolz,M. and Findl,O. (2005).Advantage of three dimensional animated teaching over traditional surgical videos for teaching ophthalmic surgery: a randomized study. British Journal of Ophthalmology. 89(11): 1495-1499.

Quinnell,R.; May,E. \& Peat,M.(2012). Conceptions of Biology and Approaches to Learning of First Year Biology Students: Introducing a technique for tracking changes in learner profiles over time. International Journal of Science Education, 34(7), 1053-1074.

Rohendi,D. (2012). Developing E-Learning Based on Animation Content for Improving Mathematical Connection Abilities in High School Students. International Journal of Computer Science 9( 4),1-5.

Ross, P. M.; Tronson, D. A.; Ritchie, R. J.(2008). Increasing Conceptual Understanding of Glycolysis \& the Krebs Cycle Using Role-Play. American Biology Teacher, 70(3), 163-168.

Stavrianeas,S. (2005).Teaching Glycosis Regulation to Undergraduates Using An Electrical Power Generation Analogy. Advances in Physical Education, 29(2),128-130.

Sugapriya G, Ramachandran C(2011).Assessing visual memory in slow learners by teaching with computer animated models.International Journal of Medical Research.2(4),946-949.

Syrjakow, M.; Berdux, J.; Szczerbicka, H.(2000). Interactive Web-based animations for teaching and learning Simulation Conference Proceedings. Winter 2 (2), 1651 - 1659 vol.2

Thoron, A. C.; Myers, B. E. (2011). Effects of Inquiry-based Agriscience Instruction on Student Achievement. Journal of Agricultural Education; 52(4), 175-176.

Verhoeff, R.P.; Waarlo,A.J. \& Boersma,K.T. (2008). Systems Modelling and the Development of Coherent Understanding of Cell Biology. International Journal of Science Education, 30(4), 543-568.

Wouters, P.J.M., Paas, F. \& van Merriënboer, J. J. G. (2008). Observational learning from animated models: Effects of modality and reflection on transfer. Contemporary Educational Psychology,34,1-8. 


\section{Appendix-I}

\section{Introduction for the Class}

Today you will be examining the numbers of mitochondrial oxidative phosphorylation. Do not write any remarks or talk about the figures during the examining. After 10 minutes of viewing, I will ask you to exit the webpage and then I'll hand out a questionnaire for you to fill out. It is imperative that you do not converse or outlook the figures while loading out the questionnaire. Please note that other than electron transport involved there is no audio or text to explain the figures so it is essential for you to visualize and interpret what you are viewing. Note that the graphics are presented in sequence with several events occurring within each panel.

\section{How to carry out the Misconception test}

In fact, to identify the misconceptions, tell the under-graduate (B.Sc.) students regarding misconception test (i.e. fifteen multiple-choice questions on chemiosmotic hypothesis topics). Tell the students to read the items and to select an option (e.g. Correct response). However, they are free to choose "correct" answer from the worksheet. Worksheet is the single and the best way to identify the actual misconceptions of prior knowledge, illustration, analysis, understanding which the students were not clarified during the last traditional classroom transaction. It is better to use answer key to check the status of misconception of the pre test.

\section{Instruction and Achievement test}

After the introduction, students open to the course homepage and then type in "/pic.htm" after the homepage url, the whole url is:

https://www.google.co.in/search?q=atp+synthesis+animation\&espv=210\&es_sm=93\&tbm=isch\&source =iu\&imgil=FmxmQnZobpxp2M\%253A\%253Bhttps\%253A\%252F\%252Fencrypted-

tbn2.gstatic.com\%252Fimages\%253Fq\%253Dtbn\%253AANd9GcReta9bYEV5Jq46b6lhaNaprOgbhztZo wyqaEGb2UEoN2ryr0eTBQ\%253B272\%253B178\%253BUhiiN9zcKPIFAM\%253Bhttp\%25253A\%25252F $\% 25252 \mathrm{Fwww}$.biologie.uni-hamburg.de $\% 25252 \mathrm{Fb}-$

online\%25252Flibrary\%25252Fmicro229\%25252Fterry\%25252F229sp00\%25252Flectures\%25252FATPsy nthbact.html\&sa=X\&ei=DN_MUqTDIXBrAee34DwCQ\&ved=0CDIQ9QEwAQ\&biw=1280\&bih=674\#fa crc=_\&imgrc=FmxmQnZobpxp2M\%253A\%3BUhiiN9zcKPIFAM\%3Bhttp\%253A\%252F\%252Fwww.bio logie.uni-hamburg.de\%252Fb-

online\%252Flibrary\%252Fmicro229\%252Fterry\%252Fimages\%252Fanim\%252FATPanim.gif\%3Bhttp\% 253A\%252F\%252Fwww.biologie.uni-hamburg.de\%252Fb-

online \%252Flibrary\%252Fmicro229\%252Fterry\%252F229sp00\%252Flectures\%252FATPsynthbact.html $\% 3 \mathrm{~B} 272 \% 3 \mathrm{~B} 178$

Suggest the student not to start viewing it until everyone has the web page with the animation on their screen; ask students to raise their hands to see if they're all ready. At that point, tell them to start, after 10 minutes tell them to stop by going to another webpage; don't answer any questions during the viewing. Hand out the questionnaires and remind them to remain silent and answer all questions to the best of their ability. Tell them they can hand in their completed questionnaires and leave when they feel they have completed the exercise. Give them a maximum of 30 minutes to read and complete the questionnaire. Say the student not to start examining it until everyone has the web page with the animation on his or her screen; ask students to raise their hands to see if they're all ready. At that issue notify them to start, after 10 minutes notify them to halt by going to another webpage; don't answer any inquiries throughout the examining. Hand out the questionnaires and remind them to stay quiet and answer all inquiries to the best of their proficiency. Tell them they can hand in their completed questionnaires and leave when they seem they have accomplished the exercise. Give them a greatest of 30 minutes to read and entire the questionnaire. 
Supplemental Material 1

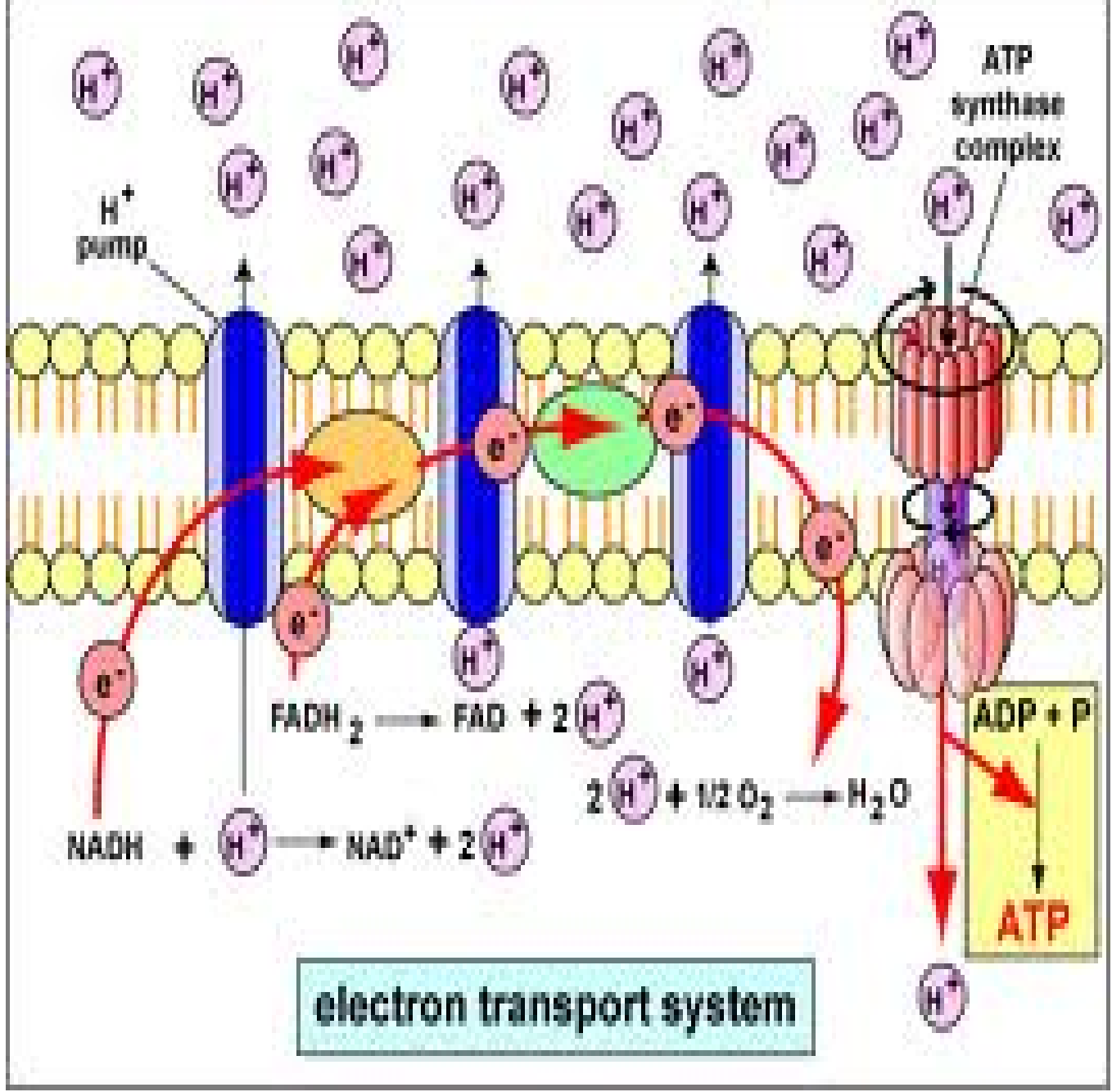

